\title{
Blood-Sparing Heart Surgery in Critically Anaemic Patients Refusing Red Blood Cell Transfusions
}

\section{Luca Weltert*}

Cardiac Surgery Department, European Hospital, Rome, Italy

\begin{abstract}
Objective: The need for allogenic blood, plasma and platelets is an unresolved dilemma in contemporary surgical practice. There is increasing evidence that transfusions worsen the prognosis and should be avoided as far as possible. Patients refusing transfusion for personal reasons but requiring urgent surgery represent a challenge to maximize blood-sparing strategies.

Methods: As the referral hospital for heart surgery in Jehova's Witnesses in Central Italy, the European Hospital of Rome has developed a multimodal strategy for blood-sparing heart surgery. This strategy has been in use since January 2006 and from early 2010 the protocol has consisted of four points: high-dose preoperative erythropoietin administration; screening and optimization of platelet aggregation and serum coagulation; intraoperative and early postoperative reinfusion of blood loss; and strict control of fluid administration.

Results: Since January 2006, 202 patients who refused any kind of transfusion have been operated on at our hospital, which represents around $4 \%$ of all people undergoing cardiac surgery at our hospital. All types of heart surgery were undertaken, with a prevalence of Coronary Artery Bypass Grafting (CABG), ascending aorta replacement and aortic valve replacement. Not a single unit of blood was transfused to these patients, whereas in a comparison group consisting of 4700 patients with an average of 1.1 units of blood per patient were used. The expected mortality as calculated by EURO score was $8.1 \%$. The overall observed mortality was $3.1 \%$, with mortality directly related to anaemia accounting for $1.6 \%$.

Conclusion: A multimodal approach to the problem of anaemia, involving optimization of preoperative haemoglobin level as far as possible in an emergency setting, optimization of coagulation and aggregation, reinfusion of lost blood intra- and perioperatively and minimizing haemodilution, allows heart surgery to be performed with a minimally increased risk in this subset of patients, casting new light on reducing the use of allogenic transfusion in the general population.
\end{abstract}

\section{Introduction}

The use of blood products in cardiac surgery is still a difficult problem in clinical practice. On the one hand their availability depends on the rate of donations, making supply inconsistent and resulting in frequent and unpredictable delays in the planning of interventions; and on the other, it is now clear that transfusion can adversely affect the patient's prognosis and outcome in both the medium and the long term $[1,2]$. In the specific context of cardiac surgery transfusion is also an independent risk factor for both the onset of acute kidney injury and the onset of atrial fibrillation [3]. These last two occurrences alone represent over $70 \%$ of postoperative morbidity and are responsible for stretches of in-hospital stay-time by over 30\% [4]. The need to avoid transfusion during major surgery is therefore a critical problem. In everyday clinical practice, however, transfusion represents a rapid and convenient short-term solution to life-threatening problems such as under perfusion of vital organs, myocardial ischaemia and renal failure $[5,6]$.

In addition, established practice firmly supports the concept that the availability and use of blood products, where clinically feasible, is essential for responsible medical practice. In an era when medicine is driven to avoid malpractice suits there is often a tendency to overtransfuse patients. However, if a patient refuses transfusion - usually for religious reasons - this cannot be ignored and so alternatives must be found [7]. To address this situation, the European Hospital in Rome, as a national centre of excellence for cardiac surgery and referral centre in Italy for cardiac surgery in Jehovah's Witnesses, has developed a strong commitment to minimize the use of transfusions. Since January 2006 many different clinical trials have been completed, all aimed at the verification of such aids as are truly effective in reducing transfusions. The results of these studies have been incorporated into a protocol to provide a smooth, reliable decision-making aid in the struggle against perioperative anaemia. The first element of this strategy is the administration of erythropoietin [8,9]. Unfortunately, the urgency of many of the conditions treated in cardiac surgery means that often advantage cannot be taken of the protocols established in the 1990s to increase the mass of circulating red blood cells (RBC), which require a delay to surgery longer than the typical heart surgery setting of three or four days. A new protocol was therefore developed for administering high doses of erythropoietin in the immediate preoperative period. The administration of $50000 \mathrm{IU}$ of erythropoietin reduced the relative risk of transfusion to 0.43 , saving approximately 0.44 blood-units per patient. During this first study we observed no adverse events of any sort, in either the short or the medium term; blood viscosity and density caused no concern, as perioperative bleeding invariably

*Corresponding author: Luca Weltert, Cardiac Surgery Department, European Hospital, Rome, Italy, Tel: +393478880617; Fax: +390665975215; E-mail: Iweltert@gmail.com

Received October 02, 2011; Accepted February 13, 2012; Published February 19, 2012

Citation: Weltert L (2012) Blood-Sparing Heart Surgery in Critically Anaemic Patients Refusing Red Blood Cell Transfusions. J Blood Disord Transfus S1:009. doi:10.4172/2155-9864.S1-009

Copyright: (c) 2012 Weltert L. This is an open-access article distributed under the terms of the Creative Commons Attribution License, which permits unrestricted use, distribution, and reproduction in any medium, provided the original author and source are credited. 
reduced the haemoglobin content and the density of the blood [10]. Encouraged by this first study we began a second study, which is still ongoing, using a single administration of 80,000 IU erythropoietin with the expectation of achieving saturation of the receptor. The preliminary results seem even better. The second element of the strategy is assessment and correction of the patient's aggregation and coagulation status [11]. In addition to a history of drug administration and withdrawal from coumadin, heparin, aspirin and clopidogrel, we routinely evaluate antithrombin and INR and, when in doubt, perform thromboelastography and aggregometry. All suboptimal results undergo complete pharmacological correction. The third element of this strategy is the recovery of intra- and postoperative blood loss. The Cell Saver System and in particular the Cardiopat system, a centrifugal pump which concentrates red blood cells extracted from the haemorrhagic fluid, are used for salvage and recovery in the first 6 hours after the operation [12-14].

A randomized study currently in press has shown that this method leads to a saving of almost 0.5 units of blood per patient (1.37 units transfused in controls vs 0.94 in the Cardiopat group). The system is versatile and can be used for any operation, but is still difficult for nurses to manage and inadequate to handle heavy intraoperative bleeding. Active collaboration with the developers will lead to the creation of a second-generation product that bridges earlier defects.

The fourth element of the strategy is a restrictive policy on fluid dilution. A simple checklist designed to check the rate of infusion of all the venous accesses can significantly reduce intraoperative haemodilution. The simultaneous use of these four strategies is our gold standard, to which it is crucial to add respect for transfusion triggers in patients who agree. For example, lowering the transfusion trigger from $8.5 \mathrm{~g} / \mathrm{dl}$ to $8.0 \mathrm{~g} / \mathrm{dl}$ in the absence of poor organ perfusion can further reduce the use of transfusion in the absence of additional risks.

\section{Material and Methods}

Although in the general population the notion of transfusion is totally acceptable, for Jehovah's Witnesses it is not.

Italian Law has established that the refusal to be transfused, when expressed by a patient with self-awareness and mental clarity and collected by a medical officer at the beginning of the inpatient episode cannot be transgressed, even when immediate survival depends on transfusion. This legal provision makes Jehovah's Witnesses extremely difficult to treat in cardiac surgery. In many cases interventions are impossible to postpone and the need to avoid anaemia is paramount in order to minimize organ ischaemia, primarily in the heart. Our particular attention to blood transfusion has made our hospital the referral centre for Jehovah's Witnesses in Italy. In this subgroup we apply the above-mentioned protocol with meticulous care, knowing that in case of failure of the strategy transfusion cannot be used. Since

\begin{tabular}{|l|l|l|l|}
\hline & $\begin{array}{l}\text { Transfusion-Refus- } \\
\text { ing Population }\end{array}$ & $\begin{array}{l}\text { Transfusion-Ac- } \\
\text { cepting Population }\end{array}$ & p Value \\
\hline Isolated CABG & $35,20 \%$ & $33,20 \%$ & 0.34 \\
\hline $\begin{array}{l}\text { Ascending aorta } \\
\text { replacement }\end{array}$ & $19,80 \%$ & $19,60 \%$ & 0.98 \\
\hline $\begin{array}{l}\text { Aortic valve } \\
\text { replacement }\end{array}$ & $20,40 \%$ & $22,40 \%$ & 0.44 \\
\hline Mitral valve repair & $15,30 \%$ & $14,90 \%$ & 0.85 \\
\hline $\begin{array}{l}\text { Mitral valve re- } \\
\text { placement }\end{array}$ & $4,10 \%$ & $3,40 \%$ & 0.34 \\
\hline Other & $5,20 \%$ & $6,50 \%$ & 0.26 \\
\hline
\end{tabular}

Table 1: Distribution by type of operation in the subpopulation analysed.
January 2006, 202 patients have categorically refused transfusion despite consenting to the intervention and its risks. This subset represents approximately $4 \%$ of the total population undergoing heart surgery at the European Hospital. The type of operation ranged from myocardial revascularization, mitral plasty and aortic valve replacement to replacement of the ascending aorta, as shown in Table 1. Only one patient needed reoperation after previous surgery. We chose to compare this population to a cohort of 4700 patients operated on in the same timeframe. We therefore conducted a retrospective cohort study, focused on mortality and adverse events. All patients' risk factors for ischaemic heart disease (family history, the presence of diabetes, hypercholesterolemia, smoking, obesity, hypertension) as well as factors included in the EUROScore analysis (age, gender, chronic pulmonary obstructive disease, the presence of extracardiac arteriopathy, neurological dysfunction, previous cardiac surgery, serum creatinine, active endocarditis, critical preoperative state, unstable angina, left ventricular dysfunction, recent myocardial infarct, pulmonary hypertension, emergency conditions, post-infarct septal rupture) and biometric parameters (height, weight and BSA) were collected and stored in the database before running a custom randomization application working in Windows XP. All deaths were recorded and categorized according to the principal initial cause and adverse events and postoperative findings were all recorded in the central database.

\begin{tabular}{|c|c|c|c|}
\hline & $\begin{array}{l}\text { Transfusion- Re- } \\
\text { fusing Population }\end{array}$ & $\begin{array}{l}\text { Transfusion- Ac- } \\
\text { cepting Population }\end{array}$ & $\begin{array}{l}p \text { Value at } \\
\text { ANOVA }\end{array}$ \\
\hline No. of patients & 202 & 4700 & \\
\hline $\begin{array}{l}\text { Family history of cardio- } \\
\text { vascular disease }\end{array}$ & $53.6 \%$ & $48.1 \%$ & 0.25 \\
\hline Obesity & $26.6 \%$ & $24.9 \%$ & 0.31 \\
\hline Diabetes & $42.6 \%$ & $38.5 \%$ & 0.12 \\
\hline Hypercholesterolemia & $54.3 \%$ & $51.7 \%$ & 0.47 \\
\hline Smoking habit & $37.1 \%$ & $41.1 \%$ & 0.33 \\
\hline Hypertension & $72.8 \%$ & $74.7 \%$ & 0.37 \\
\hline Logistic EUROScore & $8.1 \pm 7.27$ & $9.2 \pm 9.7$ & 0.25 \\
\hline Age & $68,7 \pm 9.2$ & $66.4 \pm 9.8$ & 0.12 \\
\hline Gender & $71 \%$ Male & $70 \%$ Male & 0.37 \\
\hline $\begin{array}{l}\text { Chronic pulmonary } \\
\text { obstructive disease }\end{array}$ & $26.1 \%$ & $27.5 \%$ & 0.15 \\
\hline $\begin{array}{l}\text { Presence of extracar- } \\
\text { diac arteriopathy }\end{array}$ & $22.1 \%$ & $23.8 \%$ & 0.22 \\
\hline $\begin{array}{l}\text { Neurological dysfunc- } \\
\text { tion disease }\end{array}$ & $3.4 \%$ & $4.1 \%$ & 0.31 \\
\hline $\begin{array}{l}\text { Previous cardiac } \\
\text { surgery }\end{array}$ & $4.9 \%$ & $5.4 \%$ & 0.24 \\
\hline Serum creatinine & $1.24 \pm 0.9$ & $1.33 \pm 0.4$ & 0.23 \\
\hline $\begin{array}{l}\text { Severe renal impair- } \\
\text { ment }\end{array}$ & $3.2 \%$ & $3.9 \%$ & 0.17 \\
\hline $\begin{array}{l}\text { Presence of active } \\
\text { endocarditis }\end{array}$ & $2.1 \%$ & $2.6 \%$ & 0.25 \\
\hline $\begin{array}{l}\text { Critical preoperative } \\
\text { state }\end{array}$ & $2.2 \%$ & $2.4 \%$ & 0.16 \\
\hline Unstable angina & $19.1 \%$ & $21.6 \%$ & 0.09 \\
\hline Ejection fraction & $48.5 \pm 9.2$ & $52.7 \pm 8.3$ & 0.09 \\
\hline $\begin{array}{l}\text { Recent myocardial } \\
\text { infarct }\end{array}$ & $12.7 \%$ & $13.6 \%$ & 0.21 \\
\hline Pulmonary hypertension & $5.9 \%$ & $6.3 \%$ & 0.17 \\
\hline $\begin{array}{l}\text { Postinfarct septal } \\
\text { rupture }\end{array}$ & $0.3 \%$ & $0.2 \%$ & 0.16 \\
\hline Height & $163 \pm 7$ & $165 \pm 9$ & 0.24 \\
\hline Weight & $74 \pm 15$ & $76 \pm 12$ & 0.31 \\
\hline $\begin{array}{l}\text { Baseline haemoglobin } \\
\mathrm{g} / \mathrm{dl}\end{array}$ & $13.5 \pm 1.4$ & $12.8 \pm 1.2$ & 0.16 \\
\hline
\end{tabular}

Table 2: Baseline characteristics. 


\begin{tabular}{|c|c|c|c|}
\hline & $\begin{array}{l}\text { Transfusions } \\
\text { Refusing } \\
\text { Population }\end{array}$ & $\begin{array}{l}\text { Transfusions } \\
\text { Accepting } \\
\text { Population }\end{array}$ & $p$ value \\
\hline No. of patients & 202 & 4700 & \\
\hline Blood loss at $24 \mathrm{~h}(\mathrm{ml})$ & $600 \pm 450$ & $660 \pm 380$ & 0.17 \\
\hline Intraoperative blood salvage (ml) & $370 \pm 250$ & $390 \pm 230$ & 0.11 \\
\hline Postoperative blood salvage (ml) & $350 \pm 370$ & $330 \pm 340$ & 0.12 \\
\hline Allogenic RBC transfusion (units) & 0.0 & $1.11 \pm 1.9$ & 0.02 \\
\hline $\begin{array}{l}\text { Fresh frozen plasma transfusion } \\
\text { (units) }\end{array}$ & 0.0 & $0.94 \pm 1.3$ & 0.01 \\
\hline Platelet transfusion (units) & 0.0 & $0.12 \pm 0.9$ & 0.02 \\
\hline ICU stay (days) & $2.45 \pm 1.7$ & $2.63 \pm 1.9$ & 0.31 \\
\hline Perioperative MI (\%) & $2.8 \%$ & $2.6 \%$ & 0.21 \\
\hline Peak troponin level $(\mathrm{nmol} / \mathrm{l})$ & $5.6 \pm 7.2$ & $4.7 \pm 6.5$ & 0.16 \\
\hline Epileptic syndrome (\%) & $3.9 \%$ & $3.5 \%$ & 0.17 \\
\hline Focal neurological damage (\%) & $2.4 \%$ & $2.1 \%$ & 0.10 \\
\hline $\begin{array}{l}\text { Generalized neurological damage } \\
(\%)\end{array}$ & $1.4 \%$ & $1.9 \%$ & 0.13 \\
\hline Bleeding at $6 \mathrm{~h}(\mathrm{ml})$ & $360 \pm 370$ & $330 \pm 400$ & 0.11 \\
\hline Bleeding at $12 \mathrm{~h}(\mathrm{ml})$ & $480 \pm 390$ & $510 \pm 410$ & 0.09 \\
\hline Bleeding at $24 \mathrm{~h}(\mathrm{ml})$ & $620 \pm 450$ & $640 \pm 360$ & 0.11 \\
\hline Revision for haemostasis (\%) & $3.2 \%$ & $4.5 \%$ & 0.07 \\
\hline Cardiac tamponade (\%) & $2.9 \%$ & $3.2 \%$ & 0.19 \\
\hline Atrial fibrillation (\%) & $29.2 \%$ & $33.4 \%$ & 0.04 \\
\hline $\begin{array}{l}\text { Acute respiratory distress syndrome } \\
(\%)\end{array}$ & $7.7 \%$ & $5.9 \%$ & 0.23 \\
\hline Acute pulmonary edema (\%) & $3.8 \%$ & $4.6 \%$ & 0.13 \\
\hline Pneumonia (\%) & $5.9 \%$ & $6.5 \%$ & 0.14 \\
\hline Need for reintubation (\%) & $5.6 \%$ & $5.4 \%$ & 0.13 \\
\hline Increase in liver enzymes (\%) & $6.5 \%$ & $6.9 \%$ & 0.17 \\
\hline Bowel ischaemia (\%) & $2.9 \%$ & $2.5 \%$ & 0.20 \\
\hline $\begin{array}{l}\text { Creatinine level before surgery } \\
(\mathrm{mmol} / \mathrm{l})\end{array}$ & $1.22 \pm 0.8$ & $1.29 \pm 0.7$ & 0.19 \\
\hline Maximum creatinine level $(\mathrm{mmol} / \mathrm{l})$ & $1.94 \pm 0.6$ & $2.27 \pm 0.9$ & 0.19 \\
\hline First 24-h urine output (ml) & $1820 \pm 700$ & $1740 \pm 800$ & 0.21 \\
\hline Use of fenoldopam (\%) & $7.90 \%$ & $6.70 \%$ & 0.18 \\
\hline Need for haemo-dia-filtration (\%) & $6.6 \%$ & $4.10 \%$ & 0.11 \\
\hline Need for insulin infusion (\%) & $19.0 \%$ & $17.0 \%$ & 0.10 \\
\hline $\begin{array}{l}\text { Fluid balance on discharge from } \\
\text { ICU (ml) }\end{array}$ & $540 \pm 350$ & $590 \pm 340$ & 0.11 \\
\hline $\begin{array}{l}\text { Central venous pressure on } \\
\text { discharge from ICU ( } \mathrm{mmHg})\end{array}$ & $11 \pm 3$ & $12 \pm 3$ & 0.27 \\
\hline Length of stay after operation (days) & $6.7 \pm 2.1$ & $7.2 \pm 3.0$ & 0.10 \\
\hline $\begin{array}{l}\text { Neurological complications at } 30 \\
\text { days (\%) }\end{array}$ & $2.3 \%$ & $2.2 \%$ & 0.26 \\
\hline Long-term wound infection (\%) & $5.5 \%$ & $5.7 \%$ & 0.09 \\
\hline Deep vein thrombosis (\%) & $1.7 \%$ & $2.4 \%$ & 0.03 \\
\hline Renal failure (\%) & $3.3 \%$ & $3.6 \%$ & 0.15 \\
\hline 30-day overall mortality (\%) & $3.1 \%$ & $2.7 \%$ & 0.23 \\
\hline
\end{tabular}

Table 3: Postoperative occurrences.

After discharge patients returned for a 30-day postoperative check and the follow-up file was then closed and reported for analysis.

\section{Statistical Analysis}

All data were processed by IBM SPSS version 17, including Analysis of Variance (ANOVA) and risk analysis.

The first step was to ascertain whether the two populations were comparable in terms of baseline characteristics. ANOVA of the dependent variables 'Accepting transfusion' or 'Refusing transfusion' was performed (ANOVA and UniANOVA as needed, CI 95\%, p = 0.05) on all preoperative data, namely general cardiovascular risk parameters,
EUROScore risk parameters and biometric parameters. The second step was to verify whether the two groups differed in terms of adverse events in general and mortality. Every comparison was tested with several statistical techniques (Student's t-test, Yates' continuity-corrected chisquared test), as appropriate.

\section{Results}

ANOVA confirmed the comparability of the two cohorts, as all variables analysed proved to have no statistically significant difference between the two groups, including primary disease characteristics. The baseline demographic and clinical characteristics of each group are summarized in Table 2. Table 3 shows the adverse events analysis, with differences in terms of 30-day mortality, in-hospital complications and mid-term morbidity. Briefly, the two populations did not differ for the parameters considered, except in terms of atrial fibrillation and deep vein thrombosis, which seemed to occur more frequently in the control group ( $29.2 \%$ vs $33.4 \%$, p $0.04 ; 1.7 \%$ vs $2.4 \%$, p $=0.03$, respectively) and of transfusions, which did not occur at all in the transfusion-refusing population; on the other hand, the control group required 1.1 units of blood per patient $(\mathrm{p}<0.001)$. Overall mortality was subdivided according the recorded initial cause, as shown in Table 4.Within the overall mortality in the no-transfusion subgroup we identified, albeit with a certain degree of arbitrariness, those patients in whom inability to correct the anaemia was the primary cause of a potentially preventable death. To distinguish these conditions we used blood lactate under conditions of sufficient flow measured by the thermodilution Swan-Ganz. In these cases, the presence of anaemia $<7.0 \mathrm{~g} / \mathrm{dl}$ was considered an inducer of major organ distress. This corresponds to about $1.6 \%$ of the subgroup, i.e. almost half the deaths in this category. The comparison group had no occurrences in this category, as would be expected and the inconsistency of absolute numbers (just 3 cases) in the remaining categories clearly makes statistical inference unreliable. Overall mortality was also analyzed with regard to the type of operation (Table 5), although extreme fragmentation of the reports owing to the increasing number of categories again makes any kind of statistical inference unreliable. The expected mortality in the transfusion-refusing group, calculated according to the EUROScore parameters, was $8.1 \%$ and in the comparison population was $9.2 \%$. The observed mortality rate in the transfusion-refusing group was $3.1 \%$. For comparison, in the general population mortality in the same period amounted to $2.7 \%$. The difference was not statistically significant $(p=0.10)$. Results are shown in Figure 1.

\begin{tabular}{|l|l|l|l|l|l|}
\hline Cause of Death & \multicolumn{2}{|l|}{$\begin{array}{l}\text { Transfusion- } \\
\text { Refusing } \\
\text { Population }\end{array}$} & \multicolumn{2}{|l|}{$\begin{array}{l}\text { Transfusion- } \\
\text { Accepting } \\
\text { Population }\end{array}$} & \\
\hline & $\mathrm{n}$ & $\%$ & $\mathrm{n}$ & $\%$ & $\mathrm{p}$ Value \\
\hline $\begin{array}{l}\text { Refractory myocardial insuf- } \\
\text { ficiency }\end{array}$ & 0 & $0.00 \%$ & 12 & $0.26 \%$ & 0.001 \\
\hline $\begin{array}{l}\text { Multiorgan failure( initial cause } \\
\text { bowel ischaemia) }\end{array}$ & 1 & $0.45 \%$ & 34 & $0.72 \%$ & 0.07 \\
\hline $\begin{array}{l}\text { Multiorgan failure (initial cause } \\
\text { respiratory distress syndrome) }\end{array}$ & 2 & $0.91 \%$ & 65 & $1.38 \%$ & 0.05 \\
\hline $\begin{array}{l}\text { Multiorgan failure (initial cause } \\
\text { irreversible ischaemic cerebral } \\
\text { damage) }\end{array}$ & 0 & $0.00 \%$ & 16 & $0.34 \%$ & 0.001 \\
\hline $\begin{array}{l}\text { Multiorgan failure (initial cause } \\
\text { severe and untreated anaemia) }\end{array}$ & 3 & $1.60 \%$ & 0 & $0.00 \%$ & 0.001 \\
\hline Any cause & 6 & $3.10 \%$ & 127 & $2.70 \%$ & 0.1 \\
\hline
\end{tabular}

Table 4: Causes of death in the two populations. 
Citation: Weltert L (2012) Blood-Sparing Heart Surgery in Critically Anaemic Patients Refusing Red Blood Cell Transfusions. J Blood Disord Transfus S1:009. doi:10.4172/2155-9864.S1-009

Page 4 of 5

\begin{tabular}{|c|c|c|c|c|c|c|c|c|c|c|c|c|c|c|c|c|c|c|}
\hline \multirow[t]{2}{*}{$\begin{array}{l}\text { Transfusion- } \\
\text { Refusing } \\
\text { Population }\end{array}$} & \multicolumn{3}{|c|}{$\begin{array}{l}\text { Refractory Myocar- } \\
\text { dial Insufficiency }\end{array}$} & \multicolumn{3}{|c|}{$\begin{array}{l}\text { Multiorgan Failure (Initial } \\
\text { Cause Bowel Ischaemia) }\end{array}$} & \multicolumn{3}{|c|}{$\begin{array}{l}\text { Multiorgan Failure (Inital } \\
\text { Cause Respiratory Dis- } \\
\text { tress Syndrome) }\end{array}$} & \multicolumn{3}{|c|}{$\begin{array}{l}\text { Multiorgan Failure (Initial } \\
\text { Cause Irreversible Isch- } \\
\text { aemic Cerebral Damage) }\end{array}$} & \multicolumn{3}{|c|}{$\begin{array}{l}\text { Multiorgan Failure (Initial } \\
\text { Cause Severe and Un- } \\
\text { treated Anaemia) }\end{array}$} & \multicolumn{3}{|c|}{ Any Cause } \\
\hline & $n$ & of & $\%$ & $n$ & of & $\%$ & $n$ & of & $\%$ & $n$ & of & $\%$ & $n$ & of & $\%$ & $n$ & of & $\%$ \\
\hline Isolated CABG & 0 & 71 & $0,00 \%$ & 1 & 71 & $1,41 \%$ & 0 & 71 & $0,00 \%$ & 0 & 71 & $0,00 \%$ & 0 & 71 & $0,00 \%$ & 1 & 71 & $1,41 \%$ \\
\hline $\begin{array}{l}\text { Ascending } \\
\text { aorta replace- } \\
\text { ment }\end{array}$ & 0 & 40 & $0,00 \%$ & 0 & 40 & $0,00 \%$ & 0 & 40 & $0,00 \%$ & 1 & 40 & $2,50 \%$ & 0 & 40 & $0,00 \%$ & 1 & 40 & $2,50 \%$ \\
\hline $\begin{array}{l}\text { Aortic valve } \\
\text { replacement }\end{array}$ & 0 & 41 & $0,00 \%$ & 0 & 41 & $0,00 \%$ & 0 & 41 & $0,00 \%$ & 0 & 41 & $0,00 \%$ & 2 & 41 & $4,85 \%$ & 2 & 41 & $4,88 \%$ \\
\hline $\begin{array}{l}\text { Mitral valve } \\
\text { repair }\end{array}$ & 0 & 31 & $0,00 \%$ & 0 & 31 & $0,00 \%$ & 1 & 31 & $3,24 \%$ & 0 & 31 & $0,00 \%$ & 0 & 31 & $0,00 \%$ & 1 & 31 & $3,23 \%$ \\
\hline $\begin{array}{l}\text { Mitral valve } \\
\text { replacement }\end{array}$ & 0 & 8 & $0,00 \%$ & 0 & 8 & $0,00 \%$ & 0 & 8 & $0,00 \%$ & 0 & 8 & $0,00 \%$ & 1 & 8 & $12,07 \%$ & 1 & 8 & $12,50 \%$ \\
\hline Other & 0 & 11 & $0,00 \%$ & 0 & 11 & $0,00 \%$ & 0 & 11 & $0,00 \%$ & 0 & 11 & $0,00 \%$ & 0 & 11 & $0,00 \%$ & 0 & 11 & $0,00 \%$ \\
\hline Total & 0 & 202 & $0,00 \%$ & 1 & 202 & $0,50 \%$ & 1 & 202 & $0,50 \%$ & 1 & 202 & $0,50 \%$ & 3 & 202 & $1,49 \%$ & 6 & 202 & $3,06 \%$ \\
\hline Isolated CABG & 4 & 1560 & $0.26 \%$ & 19 & 1560 & $1.22 \%$ & 13 & 1560 & $0.83 \%$ & 2 & 1560 & $0.13 \%$ & 0 & 1560 & $0.00 \%$ & 38 & 1560 & $2.44 \%$ \\
\hline $\begin{array}{l}\text { Ascending } \\
\text { aorta replace- } \\
\text { ment }\end{array}$ & 0 & 921 & $0.00 \%$ & 2 & 921 & $0.22 \%$ & 6 & 921 & $0.65 \%$ & 7 & 921 & $0.76 \%$ & 0 & 921 & $0.00 \%$ & 15 & 921 & $1.63 \%$ \\
\hline $\begin{array}{l}\text { Aortic valve } \\
\text { replacement }\end{array}$ & 4 & 1053 & $0.38 \%$ & 9 & 1053 & $0.85 \%$ & 19 & 1053 & $1.80 \%$ & 2 & 1053 & $0.19 \%$ & 0 & 1053 & $0.00 \%$ & 34 & 1053 & $3.23 \%$ \\
\hline $\begin{array}{l}\text { Mitral valve } \\
\text { repair }\end{array}$ & 1 & 700 & $0.14 \%$ & 1 & 700 & $0.14 \%$ & 15 & 700 & $2.14 \%$ & 1 & 700 & $0.14 \%$ & 0 & 700 & $0.00 \%$ & 18 & 700 & $2.57 \%$ \\
\hline $\begin{array}{l}\text { Mitral valve } \\
\text { replacement }\end{array}$ & 1 & 160 & $0.63 \%$ & 1 & 160 & $0.63 \%$ & 9 & 160 & $5.63 \%$ & 2 & 160 & $1.25 \%$ & 0 & 160 & $0.00 \%$ & 13 & 160 & $8.14 \%$ \\
\hline Other & 2 & 306 & $0.65 \%$ & 2 & 306 & $0.65 \%$ & 3 & 306 & $0.98 \%$ & 2 & 306 & $0.65 \%$ & 0 & 306 & $0.00 \%$ & 9 & 306 & $2.95 \%$ \\
\hline Total & 12 & 4700 & $0.26 \%$ & 34 & 4700 & $0.72 \%$ & 65 & 4700 & $1.38 \%$ & 16 & 4700 & $0.34 \%$ & 0 & 4700 & $0.00 \%$ & 127 & 4700 & $2.70 \%$ \\
\hline
\end{tabular}

Table 5: Causes of death in relation to type of operation.

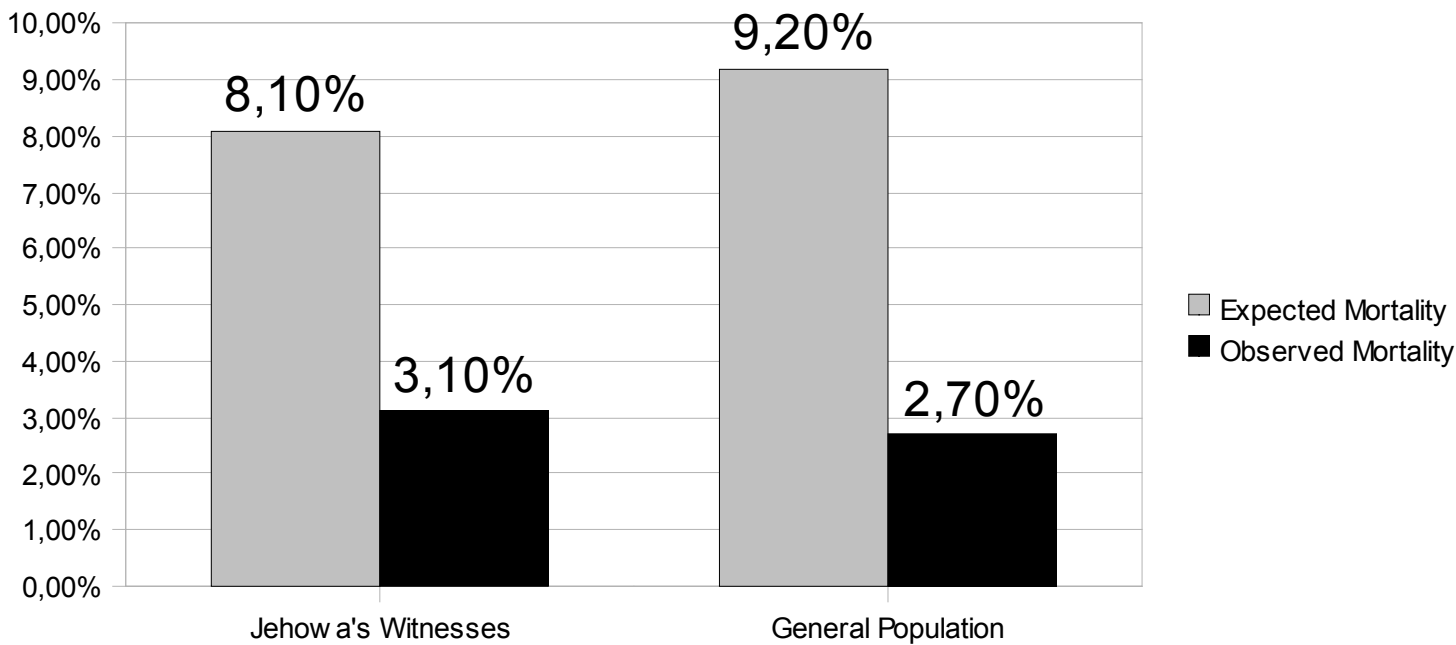

Figure 1: Observed overall mortality, no-transfusion group vs global population, compared to predicted mortality as calculated by EUROSCore. P 0.11 .

\section{Discussion}

The focus of this study was to assess whether the impossibility of transfusing red blood cells in the setting of major surgery determines an increase in risk of death and postoperative complications despite a modern and tested approach using blood-saving techniques. Blood-conservation techniques are of paramount importance in cardiac surgery, as postoperative bleeding is common and allogenic $\mathrm{RBC}$ transfusion carries the risks of clerical errors, immunological reactions and transmission of blood borne pathogens, both familiar and unrecognized. Moreover, allogenic blood products are quite expensive in their production process and represent a limited resource worldwide. Nowadays, despite all efforts, a proportion of patients undergoing cardiac surgery require allogenic RBC transfusion. The design of this study was simple and adequately powered. All patients presenting for heart surgery at our institution were eligible for the study and no exclusion criteria were applied. All variables analysed showed no statistically significant differences between the two groups. The key findings were that observed postoperative occurrences did not differ substantially and no difference could be established in terms of mortality. Despite a consistent number of studies regarding each separate aspect of blood conservation, in both general heart surgery patients and those refusing transfusion, we could find no relevant publications with regard 
to an integrated strategy such as ours and this led us to disclose our method. The ability to recruit a relatively large number of heart surgery patients within a short period also yields interesting findings, as this is intrinsically the best way to control for confounding factors due to changes in approaches, drugs and techniques over time. The study lacks the power of prospective and randomized studies, but randomization with regard to this topic could easily be illegal and hence impossible to realize. Another possible weakness is the lack of blindness: despite the strict observance of internal protocols, the awareness of not being able to transfuse can lead individuals to multiply their efforts at all times, thereby biasing the 'equal strategy' assumption.

\section{Conclusion}

This observational study shows that it is possible to perform cardiac surgery without allogenic transfusion, with a mortality rate that is acceptable and comparable to that of the general population. The results obtained in the specific subpopulation of those who refused blood transfusions might in the future be of benefit to the entire population, avoiding the detrimental effect of transfusion and bringing cardiac surgery closer to the goal of not requiring blood.

\section{References}

1. Koch CG, Khandwala F, Li L, Estafanous FG, Loop FD, et al. (2006) Persisten effect of red cell transfusion on health-related quality of life after cardiac surgery. Ann Thorac Surg 82: 13-20.

2. Koch CG, Li L, Duncan Al, Mihaljevic T, Loop FD, et al. (2006) Transfusion in coronary artery bypass grafting is associated with reduced long-term survival. Ann Thorac Surg 81: 1650-1657.

3. Koch CG, Li L, Van Wagoner DR, Duncan Al, Gillinov AM, et al. (2006) Red cell transfusion is associated with an increased risk for postoperative atrial fibrillation. Ann Thorac Surg 82: 1747-1756.
4. Saving and improving lives-National Blood Service. Annual report 2004.

5. Goodnough LT, Brecher ME, Kanter MH, AuBuchon JP (1999) Transfusion medicine. First of two parts--blood transfusion. N Engl J Med 340: 438-447.

6. Karkouti K, Wijeysundera DN, Yau TM, Beattie WS, Abdelnaem E, et al. (2004) The independent association of massive blood loss with mortality in cardiac surgery. Transfusion 44: 1453-1462.

7. Price S, Pepper JR, Jaggar SI (2005) Recombinant human erythropoietin use in a critically ill Jehovah's Witness after cardiac surgery. Anesth Analg 101: 325-327.

8. Alghamdi AA, Albanna MJ, Guru V, Brister SJ (2006) Does the Use of Erythropoietin Reduce the Risk of Exposure to Allogeneic Blood Transfusion in Cardiac Surgery? A Systematic Review and Meta-Analysis. J Card Surg 21 320-326.

9. Monk TG (2004) Preoperative recombinant human erythropoietin in anaemic surgical patients. Crit Care 8: 45-48.

10. Weltert L, D'Alessandro S, Nardella S, Girola F, Bellisario A, et al. (2010) Preoperative very short-term, high-dose erythropoietin administration diminishes blood transfusion rate in off-pump coronary artery bypass: a randomized blind controlled study. J Thorac Cardiovasc Surg 139: 621-626.

11. Diprose P, Herbertson MJ, O'Shaughnessy D, Deakin CD, Gill RS (2005) Reducing allogeneic transfusion in cardiac surgery: a randomized double-blind placebo-controlled trial of antifibrinolytic therapies used in addition to intraoperative CS. Br J Anaesth 94: 271-278.

12. Murphy GJ, Allen SM, Unsworth-White J, Lewis CT, Dalrymple-Hay MJ (2004) Safety and Efficacy of Perioperative CS and Autotransfusion After Coronary Artery Bypass Grafting: A Randomized Trial. Ann Thorac Surg 77: 1553-1559.

13. Carless PA, Henry DA, Moxey AJ, O'Connell D, Brown T, et al. (2006) Cel salvage for minimizing perioperative allogeneic blood transfusion. Cochrane Database Syst Rev 17: CD001888.

14. Klein AA, Nashef SA, Sharples L, Bottrill F, Dyer M, et al. (2008) A randomized controlled trial of cell salvage in routine cardiac surgery. Anesth Analg 107 : 1487-1495. 